\title{
Subclinical Cushing's syndrome with bilateral adrenal tumours in a patient with gallbladder multiple stone: therapeutical options
}

${ }^{1}$ Department of Endocrinology, Carol Davila University of Medicine and Pharmacy \& C.I. Parhon National Institute of Endocrinology, Bucharest, Romania

${ }^{2}$ Iuliu Hatieganu University of Medicine and Pharmacy \& Endocrinology Clinic, County Hospital, ClujNapoca, Romania

${ }^{3}$ C.I. Parhon National Institute of Endocrinology, Bucharest, Romania

${ }^{4}$ Anima Medical Centre, Bucharest, Romania

\begin{abstract}
Introduction

The field of Cushing syndrome is a various area; there are still subjects incompletely clarified as the subclinical pattern as well as cortisol producing bilateral adrenal tumours.

Case presentation

The paper presents a 67 -year old male case previously known with metabolic complications. He had an abdominal ultrasound done for unspecific complains and multiple gallbladder stones together with a right adrenal tumour were found. Later the computer tomography revealed bilateral adrenal tumours of almost 1.5 centimetres diameters (right larger than left) and a morning plasma cortisol level of 2.58 micrograms/ decilitre after low dose of dexametasone suppression test confirming the subclinical Cushing syndrome. After 6 months the endocrine and imagery profile was similar but the gallbladder patter aggravated so surgery was performed (together with right adrenalectomy) by a laparoscopic procedure. The blood pressure profile improved after surgery.

\section{Conclusion}

Subclinical Cushing syndrome diagnosis is challenging especially if metabolic complications or bilateral adrenal tumours are presented. Based on our observations in this
\end{abstract}

\section{Mara Carsote}

Bucharest, Romania, Aviatorilor Ave 34-38, sector 1, postal code 011863 fax: +40213170607 ;

phone: +40213172041 ;

email: carsote_m@hotmail.com case unilateral adrenalectomy improved the metabolic pattern.

Keywords: Cushing's syndrome, adrenal tumour, gallbladder stones, morning plasma cortisol, high blood pressure

\section{Introduction}

Little is known about the true aetiology of bilateral adrenal tumours.[1] ACTH-independent macronodular adrenal hyperplasias also called AIMAH has been recently linked to ARMC5 and PRKACA mutations in cortisol producing adenomas. $[1,2,3,4]$ The correlation to clinical or subclinical Cushing's syndrome is well established in this type of bilateral adrenal tumours. The subclinical pattern is less described and there are less consensus clear cut off in order to interfere in the clinical (especial surgical) management of these cases. [5] However most of the studies agree that a major improvement is seen regarding the blood pressure, the glucose profile if surgery is performed. [5] Some authors suggested that actually "subclinical" is not "sub" but it is very much "clinical" since adrenalectomy brings benefits in clinical status of the patient. [6] Recent concepts reveal the fact that despite the difficulties in diagnosis the clinical aspects are significant before and after surgery so a collaborative workup between endocrinologist and endocrine surgeon is useful. [7, $8,9]$ 


\section{Case presentation}

67 - year old ex smoker male had an ultrasound done one year ago for an unspecific abdominal complain. Gallbladder stones and a right adrenal tumour were found. He associated metabolic syndrome with the following components: obesity, type 2 diabetes mellitus (under oral medication), high blood pressure, high uric acid, dyslipidemia. He is currently under 100 micrograms of levothyroxine for non-autoimmune hypothyroidism. The thyroid ultrasound pointed small nodules of less than 1 centimetre suggestive for endemic goitre. He came for a second endocrine opinion at C.I.Parhon National Institute of Endocrinology, Bucharest, Romania where he was admitted for supplementary endocrine tests. The blood ionograme was normal and the glycated haemoglobin was $6.5 \%$. The medullar adrenal profile was normal. The cortical adrenal features pointes subclinical Cushing's syndrome. (Table I)

Table I. The endocrine profile in 67-year old male with bilateral adrenal tumours

\begin{tabular}{|l|l|l|l|}
\hline Parameter & Level & $\begin{array}{l}\text { Normal } \\
\text { ranges }\end{array}$ & Units \\
\hline Serum chromogranin A & 43 & $40-100$ & $\mathrm{ng} / \mathrm{mL}$ \\
\hline Basal morning cortisol & 11.06 & $6.2-19.4$ & $\mu \mathrm{g} / \mathrm{dL}$ \\
\hline $\begin{array}{l}\text { Morning plasma ACTH } \\
\text { (adrenocorticotrophic } \\
\text { hormone) }\end{array}$ & 5.9 & $3-66$ & $\mathrm{pg} / \mathrm{mL}$ \\
\hline Plasma metanephrines & 70 & $10-90$ & $\mathrm{pg} / \mathrm{mL}$ \\
\hline Plasma normetaneprines & 112 & $15-180$ & $\mathrm{pg} / \mathrm{mL}$ \\
\hline $\begin{array}{l}\text { Beta-HCG (human } \\
\text { chorionic gonadotropin) }\end{array}$ & 1.06 & $0.5-2.67$ & $\begin{array}{l}\mathrm{mIU} / \\
\mathrm{mL}\end{array}$ \\
\hline
\end{tabular}

The dexametasone suppression test ( 2 days of 2 miligrams) pointed a morning plasma cortisol of 2.58 micrograms/decilitre, meaning no perfect suppression as expected for reactive hypercortisolemia (less than a 1.8 micrograms cut off). [10] The computer tomography (CT) showed two adrenal masses of 1.33 by 1.25 by 1.05 centimetres (left) and of 1.32 by 1.45 centimetres (right). (Figure 1)

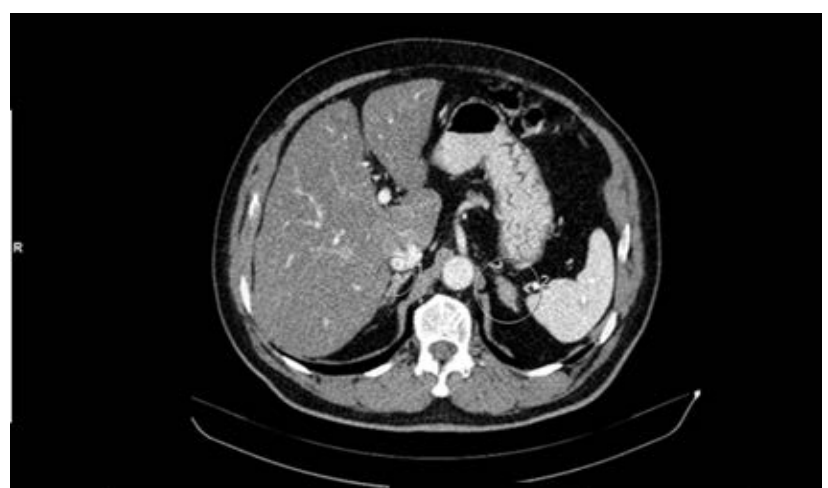

Figure1. Computer tomography pointing two bilateral adrenal tumours in a 67-year old male with subclinical Cushing syndrome

The patient was followed for 6 more months but the endocrine and imagery features were unchanged while the gallbladder stones had increased dimensions up to 2.98 by 2.22 centimetres. Based on gallbladder stone and the fact that the larger tumour was on the same side the decision of surgery was taken. The laparoscopic procedure was performed without incidents during and immediately after the procedure. The histological report showed a cortical corticoadenoma with benign features and no gallbladder malignancy yet with multiple stones. (Figure 2)

Clinical improvement in blood pressure was registered soon after the procedure. The patient will be systematically checked up

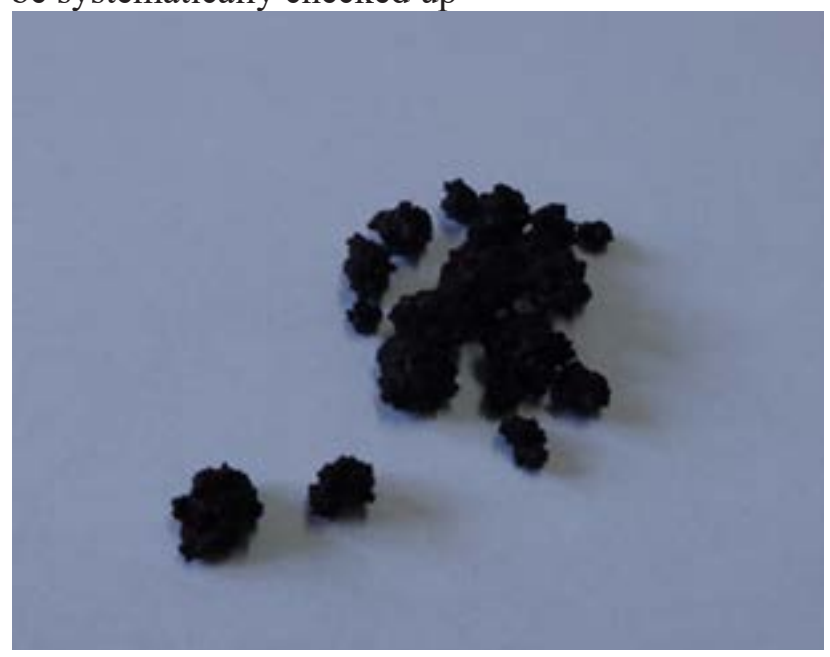

Figure2. Gallbladder multiple stones that were removed in one time laparoscopic procedure together with right adrenal 
This is an interesting case of subclinical Cushing's syndrome in a patient with bilateral adrenal tumours who previously associated metabolic complications. The component cause by high cortisol levels probably aggravates the metabolic pattern. After surgery the need for hypo-tensors was lower but a normalisation of the entire metabolome pictures is mostly unlikely.

Generally the corticotrophin independent Cushing syndrome is found in $80-85 \%$ of cases and $60 \%$ of them are benign lesions while less than $2 \%$ are bilateral adrenal tumours/macronodular hyperplasia. [11] The female/male ratio is one in this last situation. [11] New data suggested that the ratio is actually 2-3: 1 in favour of women. [12] Salivary cortisol might be an elegant alternative to the diagnosis but it is not routinely used in Romania. [13] The previous metabolic complications in patients with adrenal incidentaloma might increase the index of suspicion. $[14,15]$ In case of bilateral lesions the lateralisation of the disease in order to indicate the first step in surgical approach is indicated by methods as abdominal/ adrenal ultrasound or computed tomography in favour or bilateral catheterisation which is not available in many medical centres. [16] Performing the surgery is useful for further cardiovascular good changes. [17, $18]$

\section{Conclusion}

Subclinical Cushing syndrome is a delicate diagnosis especially in patients with metabolic complications or bilateral adrenal tumours. Based on our observations in this case unilateral adrenalectomy improved the metabolic pattern.
We thank to the patient for giving us the informed written consent and to the entire medical team. Special thanks to dr. Razvan Petrescu, surgeon at Military Emergency Hospital, Bucharest, Romania.

\section{References}

1. Haissaguerre, M. \& Tabarin, A. (2014). New insights in adrenal Cushing syndrome. Ann Endocrinol. 75(1)S, 37-45.doi: 10.1016/S00034266(14)70025-3.

2. Drougat, L, Omeiri, H., Lefèvre, L. \& Ragazzon, B. (2015). Novel Insights into the Genetics and Pathophysiology of Adrenocortical Tumors. Front Endocrinol (Lausanne), 6, 96. doi: 10.3389/fendo.2015.00096. eCollection 2015.

3. Espiard, S. \& Bertherat, J. (2015). The Genetics of Adrenocortical Tumors. Endocrinol Metab Clin North Am. 44(2),311-334. DOI: 10.1016/j. ecl.2015.02.004.

4. Duan, K., Hernandez, G.K. \& Mete, O. (2015). Clinicopathological correlates of adrenal Cushing's syndrome. J Clin Pathol. 68(3):17586. doi: 10.1136/jclinpath-2014-202612. Epub 2014 Nov 25.

5. Mauclère-Denost, S., Duron-Martinaud, S., Nunes, M., Gatta, B., Fagour, C., Rault, A., Gosse, P. \& Tabarin, A. (2009). Surgical excision of subclinical cortisol secreting incidentalomas: Impact on blood pressure, BMI and glucose metabolism.Ann Endocrinol. 70(4),211-7. DOI: 10.1016/j.ando.2009.03.005. Epub 2009 May 19.

6. Mitchell, I.C., Auchus, R.J., Juneja, K., Chang, A.Y., Holt S.A., Snyder, W.H. 3rd \& Nwariaku, F.E. (2007). "Subclinical Cushing's syndrome" is not subclinical: improvement after adrenalectomy in 9 patients. Surgery. 142(6),900-5; discussion 
905.e1.

7. Starker , L.F., Kunstman, J.W. \& Carling, T. (2014). Subclinical Cushing syndrome: a review. Surg Clin North Am. 94(3), 657-68. doi: 10.1016/j.suc.2014.02.008. Epub 2014 Apr 24.

8. Iacobone, M., Citton, M., Viel, G., Boetto, R., Bonadio, I., Mondi, I., Tropea, S., Nitti, D. \& Favia, G. (2012). Adrenalectomy may improve cardiovascular and metabolic impairment and ameliorate quality of life in patients with adrenal incidentalomas and subclinical Cushing's syndrome. Surgery. 152(6), 991-7. doi: 10.1016/j. surg.2012.08.054.

9. Iacobone, M., Citton, M., Scarpa, M., Viel, G., Boscaro, M. \& Nitti, D. (2015). Systematic review of surgical treatment of subclinical Cushing's syndrome. Br J Surg. 102(4), 318-30. doi: 10.1002/bjs.9742. Epub 2015 Feb 2.

10. Nieman, L.K., Biller, B.M., Findling, J.W., Newell-Price , J., Savage, M.O., Stewart, P.M. \& Montori, V.M. (2008). The diagnosis of Cushing's syndrome: an Endocrine Society Clinical Practice Guideline. $J$ Clin Endocrinol Metab. 93(5), 1526-40. doi: 10.1210/jc.2008-0125. Epub 2008 Mar 11.

11. Newell-Price, J., Bertagna, X., Grossman, A.B. \& Nieman, L.K. (2006). Cushing's syndrome. Lancet. 13;367(9522), 1605-17.

12. Lacroix, A., Feelders, R.A., Stratakis, C.A. \& Nieman, L.K. (2015). Cushing's syndrome. Lancet. 21. pii: S0140-6736(14)61375-1. doi: 10.1016/S0140-6736(14)61375-1.

13. Sereg, M., Toke, J., Patócs, A., Varga, I., Igaz, P,. Szücs, N., Horányi, J., Pusztai, P., Czirják,S., Gláz, E., Rácz, K. \& Tóth, M. (2011).Diagnostic performance of salivary cortisol and serum osteocalcin measurements in patients with overt and subclinical Cushing's syndrome. Steroids. 76(1-2), 38-42. doi: 10.1016/j.steroids.2010.08.007.

14. De Leo, M., Cozzolino, A., Colao, A. \& Pivonello, R. (2012).Subclinical Cushing's syndrome. Best Pract Res Clin Endocrinol Metab. 26(4),497505. doi: 10.1016/j.beem.2012.02.001. Epub 2012 May 22.

15. Poiana, C., Chirita, C., Carsote, M., Hortopan,
D., Ioachim, D., Corneci, C.M. \& Stanescu, B. (2013). Adrenal and Pituitary Incidentalomas in a Case of Cusshing' s Syndrome. Chirurgia. 108(6), 886-891

16. Li, Z., Zhu, Y., Kong, C., Yin, L., Gao, Z., Zhao, W. \& Gong, D. (2011). Corticotropinindependent Cushing's syndrome in patients with bilateral adrenal masses. Urology. 77(2),417-21. doi: 10.1016/j.urology.2010.09.045. Epub 2010 Dec 16.

17. Aulinas, A. Valassi, E. \& Webb, S.M. (2014). Prognosis of patients treated for Cushing syndrome. Endocrinol Nutr., 61(1),52-61. doi: 10.1016/j.endonu.2013.03.008. Epub 2013 Jul 3.

18. Sippel, R.S., Elaraj, D.M., Kebebew, E., Lindsay ,S., Tyrrell, J.B. \& Duh, Q.Y. (2008) Waiting for change: symptom resolution after adrenalectomy for Cushing's syndrome. Surgery. 144(6),105460. discussion 1060-1. doi: 10.1016/j. surg.2008.08.024. 